\title{
Hf Isotope Constraints on the Genesis of Kimberlitic Megacrysts: Evidence for a Deep Mantle Component in Kimberlites
}

\author{
Nowell, G.M. ${ }^{1.2}$, Pearson, D.G. ${ }^{1}$
}

1. Department of Geological Sciences, Durham University. South Road, Durham DH1 3LE, U.K.

2. NERC Isotope Geosciences Laboratory, Kingsley Dunham Centre, Keyworth, Nottingham NG12 5GG. U.K.

\section{Introduction}

Although the relationship between megacrysts and the host kimberlite remains somewhat uncertain, there is agreement on certain aspects of megacryst petrogenesis (Jones, 1987; Hopps et al.. 1992; Griffin et al., 1997). Rare earth element (REE) and isotope geochemistry of garnet (gt) and clinopyroxene (cpx) megacrysts show that this megacryst parent magma was alkalic or picritic and probably derived from a sub-lithospheric source similar to that for ocean island basalts (OIB). The megacryst parental magma, often referred to as a 'protokimberlite' ('pk'), may eventually evolve toward kimberlitic compositions through the interaction and assimilation of enriched lithospheric mantle. Megacrysts therefore provide an important opportunity to determine the trace element and isotopic composition of a precursor kimberlite magma. Group I kimberlites are displaced below the mantle-crust array in Hf-Nd isotope space, which may indicate a deep source region (Nowell et al., 1998a). Megacrysts should allow a less lithosphere-contaminated view of the isotopic composition of the 'pk' and hence allow further evalutaion of this hypothesis. We analysed three ilmenite (ilm) megacrysts from the Frank Smith (2 plus 1 repeat) and Monastery (1) kimberlites which have been shown to crystallised from a single batch of parent magma (Moore et al., 1992; Griffin et al., 1997). Ilmenites are ideal megacrysts for $\mathrm{Hf}$ isotope studies for 2 reasons: (1) high Hf content of ilmenites $(>20 \mathrm{ppm})$ renders them less susceptible to host-kimberlite $(<1$ to $10 \mathrm{ppm} \mathrm{Hf})$ contamination and (2) the $\mathrm{Lu} / \mathrm{Hf}$ ratio of ilmenites is extremely low, generally $<3 * 10^{-5}$. The measured $\mathrm{Hf}$ isotope ratio can therefore be regarded an intial ratio.

\section{Results and Discussion}

A calculated rare earth element (REE) profile for the liquid in equilibrium with an ilm megacryst from Frank Smith is consistent with melts calculated to be equilibrium with cpx and gt megacrysts (Jones, 1987); both suggest the parental magma was an alkaline or picritic OIB-like melt (Figure 1). Given that $\mathrm{Sr}-\mathrm{Nd}-\mathrm{Pb}$ data for megacrysts also suggest an OIB-like origin, we expected that the ilm megacrysts would simply plot within the OIB field in $\mathrm{Hf}-\mathrm{Nd}$ isotope space. However, preliminary $\mathrm{Hf}$ isotope data for ilm megacrysts (Figure 2) suggest this is not the case.

The $\Delta \varepsilon H f$ notation used in Figure 2 depends on the $\varepsilon H f$ and $\varepsilon N d$ values calculated for the ilm megacrysts; this, in turn, depends on the age of megacryst formation. Jones (1987), Hopps et al. (1992) and Griffin et al (1997) have all hypothesised a genetic relationship between the megacrysts and host kimberlites. We have therefore assumed the ilm formation ages to be around close to those of the kimberlite pipe ages, i.e. 88Ma for Monastery and 114Ma for Frank Smith. As yet, Nd isotope data for the ilm megacrysts is unavailable so these have been arbitrarily assigned the $\varepsilon N d$ of the host kimberlite. This is not inappropriate given that $\mathcal{E N d}$ values for cpx and gt megacrysts have been shown to be similar to those of Group I kimberlites (Jones, 1987). Also shown in Figure 2 is the possible range in ilm $\Delta \varepsilon H f$, assuming the $\mathcal{E N d}$ value for ilmenites is equivalent to the maximum and minimum $\mathcal{E N d}$ observed for Group I kimberlites (shown as heavy vertical lines). As cpx and gt 
megacrysts have a restricted range in $\varepsilon N d$ of between 2 and 5, ilm megacrysts should prove to be similar. If correct in which case their $\Delta \varepsilon H f$ will be in the lower end of the range illustrated in Figure 2. Despite the uncertainty in the $\varepsilon N d$ of the ilm megacrysts, it would appear that unless their $\mathcal{E N d}$ is much less than that determined on cpx and gt megacrysts, the ilmenites are characterised by negative (-ve) $\Delta \varepsilon$ Hf signatures quite unlike any OIB magmas.

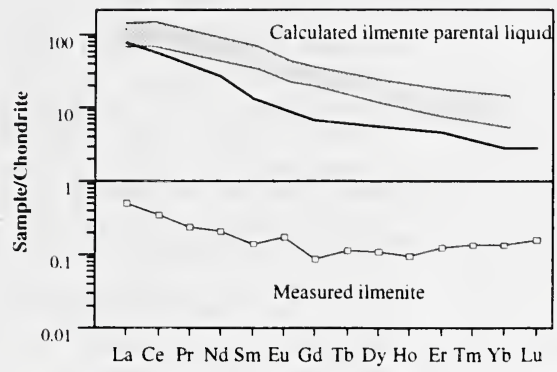

Figure 1. Chondrite normalised calculated REE profile for a liquid calculated to be in equilibrium with a Frank Smith ilmenite megacryst. Ilmenite partition coefficients used to calculate the liquid composition are from Fujimaki et al., 1984. Shaded area is range of parental liquid compositions calculated from cpx megacrysts from Monastery (Jones, 1987).

Trace element and isotopic evidence suggests that the megacryst parental magma could assimilate enriched lithosphere during megacryst formation (Jones, 1987), in which case it is possible that the $\Delta \varepsilon H f$ signatures of the ilmenites might simply reflect lithospheric contamination of the parent magma. Simple mass balance considerations, however, suggest that this is unlikely, even if the lithosphere itself is characterised by -ve $\Delta \varepsilon \mathrm{Hf}$ signatures. The $\mathrm{Hf} / \mathrm{Nd}$ ratio for a range of iithospheric lithologies $(<0.1$ : G.Pearson, unpub data) is considerably lower than that calculated for the ilm megacryst parental magma (0.3); thus, lithospheric contamination would drive the megacryst magma toward -ve $\varepsilon N d$ and higher $\Delta \varepsilon H f$ values, irrespective of whether the lithospheric component had positive or -ve $\Delta \varepsilon H f$. Therefore, if lithospheric contamination of the megacryst parental magma has occurred, its original $\Delta \varepsilon H f$ composition would be even more negative than that suggested by the ilmenite compositions.

If the megacryst magma itself is characterised by -ve $\Delta \varepsilon H f$ values, as would appear to be the case, this signature must have a sub-lithospheric origin and may therefore represent a globally widespread reservoir. Indeed, initial $\mathrm{Hf}$ isotope data from our $\mathrm{U}-\mathrm{Pb}-\mathrm{Hf}$ study of ziron megacrysts from Siberian kimberlites suggests the parental megacryst magma in this region was also characterised by -ve $\Delta \varepsilon H f$ values (between -1 to -4.5 for a range of $\varepsilon N d$ values of +2 to +5 ). Such -ve $\Delta \varepsilon H f$ values can only develop in a source which contains a component of an ancient melt generated in the presence of residual garnet. Although the -ve $\Delta \varepsilon H f$ component has a sub-lithospheric origin, the necessity for its long-term isolation clearly rules out the convecting upper mantle as the source for the megacryst magma. The $\Delta \varepsilon H f$ component must also reside deep enough in the mantle such that it does not contribute significantly to modern oceanic basalts. The most plausible candidate for this -ve $\Delta \varepsilon H f$ component, if not old lithoshere, is old subducted oceanic crust at either the $670 \mathrm{~km}$ discontinuity (Ringwood et al., 1991) or the D" (Haggerty, 1994).

The strikingly -ve $\Delta \varepsilon H f$ values of kimberlites themselves (Nowell et al., 1998a) are consistent with the signature observed for ilmenite megacrysts. This similarity in $\Delta \varepsilon H f$ further supports the notion of a genetic link between group I kimberlites and megacrysts. The same -ve 
$\Delta \varepsilon H f$ values are also observed in group II kimberlites, and from the above considerations it follows that the signatures of group I and II kimberlites may be inherited from a deep mantle component.

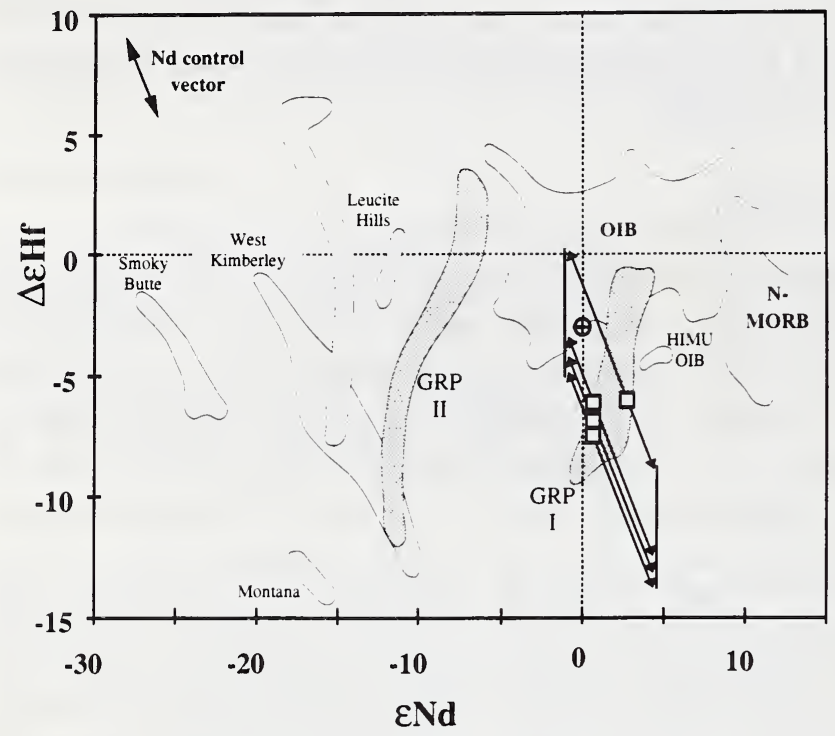

Figure 2. $\Delta \varepsilon H f$ versus $\varepsilon N d$ for ilmenite megacrysts from $S$. African Group I kimberlites. $\Delta \varepsilon \mathrm{Hf}$ is from Johnson and Beard (1993). Hf isotope data are normalised to a ${ }^{176} \mathrm{Hf} /{ }^{177} \mathrm{Hf}$ ratio for JMC 475 of 0.28216 (Nowell et al.. 1998c). During analysis of the megacrysts the external reproducibility for the $\mathrm{Hf}$ standard JMC 475 was $49 \mathrm{ppm}$ (2sd. $\mathrm{n}=29$ ). As an indication of possible sample haterogeneity. two analyses of PHN 3241-ILl (two separately picked fractions of the same megacryst) gave a reproducibility of $127 \mathrm{ppm}(2 \mathrm{Ssd})$.

\section{Conclusions}

The calculated REE profile for a liquid in equilibrium with an ilmenite megacryst is consistent with models which suggest that the megacryst parental magma is an asthenosphere-derived OIB-like alkalic/picritic melt. However, the -ve $\Delta \varepsilon H f$ signature of ilmenites and by implication their parental magma is quite unlike OIB or melts known to have originated in the convecting mantle. As megacryst parental magmas have a sub-lithospheric origin, this implies that there must exist a -ve $\Delta \varepsilon H f$ reservoir in the deep mantle. The most plausible candidate for this $\mathrm{Hf}$ reservoir is ancient subducted oceanic crust that was originally generated in the presence of residual garnet. The megacrysts therefore support models where kimberlite parent magmas are derived ultimately from very deep sources, either 670km or perhaps D” (Ringwood et al., 1991, Haggerty, 1994)

\section{References}

Fujimaki, H., Tasumoto, M., and Aoki, KI, 1984, Parition Coefficients of Hf, Zr, and REE batween Phenoorysts and Groundmasses: Journ. Geophys. Res., 89, p. 662-672

Griffin, W.L., Moore, R.O., Ryan, C.G., Gurney, J.J., and Win, T.T., 1997, Geochemistry of Magnesian Ilmenite Megacrysts from Southern African Kimberlites: Geologiya I. Geofizika 38, p. 421-443.

Haggerty, S.E., 1994, Superkimberlites: A Geodynamic Window to the Eath's Core: Earth Planet. Sci. lat., 122, p. 57-69.

Hops, J.J., Gurney, JJ., Harte, B., 1992, The Jagersfontein Cr-poor Megacryst Suite- Towards a Model for Megacryst Parogenesis: J. Volcan and Geotherm. Res., 50, p. 143-160.

Johnson, C.M., and Beard B.L., 1993, Evidence from Hafnium Isotopes for Ancient Sub-Oceanic Mantle Beneath the Rio Grande Rift Region, S.W. U.S.A: Naure, 362, p. 441-444.

Jones, R.A., 1987, Strontium and Neodymium Isotope and Rare Earth Element Evidence for the Genesis of Megacrysts in Kimberlites of Southern Africa In Nixon (1987), p. 711-724.

Moore, R.O., Griffin, W.L., Gurney, JJ., Ryan, C.G., Cousens, D.R., Sie, S.H., and Sutter, G.F., Trace Element Geochemistry of Imenite Megacrysts from the Monastery Kimberlite, South Africa Lithos, 29, p. 1-18.

Nowell, G.M., Pearson, D.G., Kempton, P.D., Noble, S.R., and Smith, C.B., 1998a, The Source Regions/Components of Kimberlites: Constraints from HfNd Isotope Systematics: this volume.

Nowell, G.M., Kempton, P.D., Noble, S.R., Fitton, J.G., Saunders, A.D., Mahoney, J.J., and Taylor, R.N., 1998c, High Precision Hf Isotope Measurements of MORB and OIB by Thermal Ionisation Mass Spectromary: Insights into the Depleted Mantle. Isotope Geoscience, in press.

Ringwood, A.E., Kesson, S.E., Hibberson, W., and Ware, N., 1992, Origin of Kimberlites and Related Magmas: Eath Planet. Sci. lat., 113, p. 521-538. 